HEALING THE SCARS:

\title{
A THEOLOGICAL-HERMENEUTICAL ANALYSIS OF VIOLENCE FROM THE PERSPECTIVES OF BOTH PERPETRATORS AND VICTIMS
}

\begin{abstract}
Christo Thesnaar
Practical Theology

Stellenbosch University

Those who cannot remember from the past

are condemned to repeat it.

Life can only be understood backward

but must be lived forward.

Søren Kierkegaard

Abstract

Violence is a reality within the South African society and it has a devastating effect on the victims, the perpetrators and the society at large. The recent outbreak of xenophobic violence in De Doorns in the Western Cape, and the violence that accompanied the service delivery protests indicates that many people have reached the point where they believe that violence is the only way to deal with the past, as well as with the current situation in South Africa. Perpetrators use violence to get what they want. In return, victims of this violent behaviour employ violence to retaliate, and in so doing the violence takes on a cycle character that soon spins out of control. This article will try to illustrate the importance of a responsible theological pastoral hermeneutic in dealing with violence from the perspectives of both the victim and the perpetrator. It will firstly indicate the importance of using a theological pastoral hermeneutic paradigm in dealing with the issue of violence; secondly it will focus on understanding the context of the violence within our country; and finally, it will indicate some ideas on how we can use this analysis to assist both the victim and the perpetrator on their journey towards healing and wholeness.
\end{abstract}

Key Words: Violence, Perpetrator, Victim, Intercultural Hermeneutic, Healing

\section{Introduction}

Since the inauguration of the first democratically elected State President and Cabinet in the early nineties the challenge to transform South Africa has headed the agenda of the government. A Truth and Reconciliation Commission (TRC) was immediately set up to assist the nation in dealing with its past in order to move on to a new future. The country adopted a new constitution and established a Human Rights Commission to ensure that the rights and dignity of all South Africans are being acknowledged. Among others, it also constructively worked to transform institutions such as the judiciary, military, police, education and all government departments and is constantly working towards eradicating poverty, providing housing and focusing on land reform. In spite of these constructive measures and many others, government and society have not managed to address the divisions amongst the people of South Africa successfully. These divisions are mainly 
based on race, the legacy of apartheid, the widening gap between rich and poor, as well as poor service delivery to those who need it most.

These growing divisions within the South African society have caused many people to become disillusioned with the ability of the government to transform the nation and eradicate poverty. This has led to a growing frustration amongst the people of South Africa over the last 15 years that manifested in various forms of violence. ${ }^{1}$ Social evils such as the high levels of corruption, crime, the molesting of children, rape, domestic violence, aids, alcohol and drug abuse, fraud, intolerance, etc. are symptoms of a nation battling to come to terms with the past and ongoing poverty. Swart (2008:147) confirms in his research that there is a definite connection between poverty and violence. The recent outbreak of xenophobic violence in De Doorns in the Western Cape, ${ }^{2}$ and the violence that accompanied the service delivery protests indicates that many people have reached the point where they believe that violence is the only way to deal with the past, as well as with the current situation. More devastating is that people believe they can employ violence to deal with violence. ${ }^{3}$ A term that can describe this is counter-violence as indicated by Stevens, Seedat \& Van Niekerk (2003:354); although these violent actions are probably best described as a cycle that spirals into devastation.

In this regard, Nell (2008:6) refers to Rene Girard's concept of the cycle of violence. Perpetrators use violence to get what they want. In return, victims of this violent behaviour employ violence to retaliate, and in so doing the violence takes on a cycle character that soon spins out of control. This pattern of the current violence in South Africa is not a recent or isolated event. This is evident in nations such as Kosovo and many African countries. Through the centuries there were times that the one group was the victim today and perpetrator the next day. Violence can therefore become epidemic to a society. In this regard, one can safely state that violence has the ability to generate violence by itself. It is about violence and counter-violence. We all need to realize that we as human beings have the capacity to be both victim and perpetrator.

Violence is a reality within the South African society and it has a devastating effect on the victims, the perpetrators and the society at large. It is therefore essential to define violence in order to understand the extent thereof. Steven and Lockhat (2003:136-7) opted for a contextual definition of violence by Bulhan (1985) who states that violence is any relation, process, or condition by which an individual or group violates the physical, social and/or psychological integrity of another person or group. On these grounds they state that any situation of oppression is therefore underwritten by violence. Nell (2008:4) can therefore make the assumption that violence can be structural and institutional. In this sense, the definition by Steven and Lockhat (2003:136-7) permits us to see poverty, forced

1 See the quotation of Vogelman in Nell, 2008, regarding the legacy of internalized violence and violent behaviour: "Today's violence is rooted in history - it is the ghost of apartheid come back to haunt its creators. One must look at that legacy to understand this upsurge of violence. It has bred social deprivation, fostering frustration and the potential for violence. This does not always take the form of political violence, but permeates society through increased crime rates, murder, rape, wife battery and child abuse."

See the article by Gerber in Die Burger, Wednesday, 18 November 2009: Xenofobie-sweer bars.

In terms of violent behaviour the South African Police Service's Crime Statistics in South Africa (2009:1) reports that 2098229 (approximately 2.1 million) crimes were registered in 2008/2009 in the Republic of South Africa. These crime statistics are broken down into various categories and one of the categories is contact crime or crime against the individual person. These contact crimes are subdivided into murder, attempted murder, sexual offences, assault with the intent to inflict grievous bodily harm, common assault, aggravated robbery and other forms of robbery. Of the approximately 2.1 million crimes registered, almost 700000 of these were contact crimes. The latter thus constitute $32.7 \%$ - almost one third - of the total crime statistics. 
removals, lack of access to health services, separate and unequal education, and lack of adequate housing, over and above political tortures and murder, ongoing racial, domestic violence and xenophobic violence as part of the same offence. These oppressive conditions have had profound economic, structural, social and psychological consequences for the majority of black people within South Africa.

In relation to the abovementioned types of violence Stevens, Seedat \& Van Niekerk $(2003: 356)^{4}$ distinguish between three types of violence: inter-personal, self-directed and organized violence. This distinction not only indicates and elucidates the types of violence but it emphasizes the extent of violence on human beings and a society.

This article will try to illustrate the importance of a responsible theological pastoral hermeneutic in dealing with violence from the perspectives of both the victim and the perpetrator. It will firstly indicate the importance of using a theological pastoral hermeneutic paradigm in dealing with the issue of violence; secondly it will focus on understanding the context of the violence within our country; and finally, it will indicate some ideas on how we can use this analysis to assist both the victim and the perpetrator on their journey towards healing and wholeness.

\section{Hermeneutical Engagement}

Both reciprocity and interpretation imply that the most appropriate paradigm for doing theology is hermeneutics. It has something to do with explanation, speech, with translation, with communicating a message, with interpreting something for people who want to hear and understand (Smit 1998:276). Practical theology is in essence hermeneutical because it has to do with understanding and the latter, according to Sinn (2008:582), is a fundamental element of the human condition itself.

A hermeneutical process is also a deeply transformative process. It is the process that involves the interpretation of the meaning of the interaction between God and humanity, the edification of the church and becoming engaged in praxis through communities of faith in order to transform the world or to impact on the meaning of life (Louw 1998:97). The church cannot therefore be a static place. It has to be a space that enables transformation (Sinn 2008:589) and meaning. Therefore, practical theology tries to interpret and translate the praxis of God in terms of human and existential issues through the action of communities of faith. This implies the ministry of the church in the world.

The goal of pastoral care is to understand the encounter between God and humans from the perspective of the confronting effect of God's grace, presence and identification with

$4 \quad$ They use the definition of violence from the WHO task force (WHO 1996) who distinguishes between these three types of violence in the following way: Inter-personal violence encompasses violent behaviour that occurs between individuals, but are not planned by any social or political groups in which they participate. It occurs in many forms, and can be grouped into three categories according to the victim-perpetrator relationship: family and intimate violence, violence amongst acquaintances and stranger violence. Violence between acquaintances and strangers also includes: workplace violence (including healthcare institutions and prisons); violence in schools (including bullying); community-based violence (that does not further the aims of a formally defined group or cause); youth violence (that does not further the aims of a formally defined group or cause); sexual violence between strangers or acquaintances; and crime-related violence. Self-directed violence involves intentional harmful behaviour directed at oneself.

Organized violence is violent behaviour planned to achieve the specific objectives of a social or political group. It includes political violence involving carefully executed efforts to intimidate an opposing political faction violently. Genital mutilation of women and men in the name of religious and cultural rites of passage may also be considered a form of organized violence. As a last example, war is the most highly organized form of violence. 
human need and suffering. It interprets this confrontation in such a way that God's care reveals a horizon of meaning, which in turn gives hope and generates faith (Louw 1998:99).

In terms of the earlier point on transformation and the abovementioned focus on meaning and hope, Veltkamp (1988:229) emphasizes that it is about the quest for a way to reach understanding and change, to make progress in one's story in the light of the story of salvation. Pastoral care is therefore essentially about listening and seeking to understand and interpret in order to find meaning within the hope of the resurrected Christ, the indwelling of his Spirit and the coming of Christ (eschatology).

Sinn (2008:589) argues in her concluding remarks on what a hermeneutical reflection can offer to ecclesiology that a hermeneutical process is a deeply relational process. Thiselton (2007:236) rightly says that understanding relationships and communities grows out of a fuller understanding of God as Trinity. He quotes Moltmann who explicitly attacks a 'metaphysical' notion of divine immutability. Moltmann explains this by stating that a God who cannot suffer cannot love either. In this sense, Louw (1998:14) states that he is convinced that a pastoral hermeneutics can only be exercised in a meaningful manner when it is understood as a hermeneutics of the cross. Pastoral hermeneutics is therefore not only about God's relationship with us and our relations with each other but is also about restoring the relationship with us and with each other. To focus on restoring the relationships with one another we need to require wisdom from God. We need wisdom theology. According to Louw (1995:50), wisdom theology has to do with relationships on all levels, it always has justice and reconciliation as its goal, it always influences the deeds and operations of the believer and it is formed through the principle of shalom (a Biblical understanding of shalom implies both structural issues and human issues in a social context).

The hermeneutical challenge is how to move from the Biblical text to a current understanding of human identity within the context of the perpetrator and victim. Within the hermeneutical paradigm, the perpetrator and the victim need to be understood within their context as being fully human beings, as relational human beings who are seeking healing and wholeness. Both are affected and need healing so that the relationships can be restored and they can continue on their life journey. According to Kraybill (1992:20), this is possible via a process of conscientization: "Conscientization is partly a matter of open acknowledgement within one group about the ways in which that group has been injured by other groups. One of the odd characteristics of group hurt is that it often so pervades the lives of members of an oppressed group that members lose awareness of the depth of their injury. They are aware that life is difficult, but they are not sure why and are often blaming themselves or their group for their problems."

Pastoral care within a hermeneutical paradigm also has to do with a theology of life and the healing of life. It is about the dwelling in the presence of the pathos of the suffering Christ. It is about the question how the perspective of the resurrection in Christ, and the indwelling presence of his Spirit, can contribute to the empowerment of human beings. It is about hope, care and the endeavour how to give meaning to life within the reality of suffering, our human vulnerability, and the ever existing predicament of trauma, illness and sickness (Louw 2008:11).

In terms of the South African context we need to understand that human beings cannot be understood in isolation from cultural issues and values. Both the perpetrator and the victim are embedded in culture. Culture in itself is an expression of the creative and imaginative human spirit. In itself it can be viewed as a sacred endeavour. Pastoral care from a hermeneutical paradigm within the South African context is not possible without an intercultural paradigm. That is the reason why Louw (2008:153) comments: "In an 
intercultural hermeneutical model, we don't anymore work with the split between Christ and culture (see Niebuhr), but with the interconnectedness between Christ and culture. In interculturality it is about the meaning of Christian spirituality within culture, as well as the mutual influence and exchange of paradigms between the two. Although one cannot ignore the tendencies of against (anti), assimilation, accommodation, paradox and transformation, the tension between exclusiveness and inclusiveness, between continuity and discontinuity (they will always be existent and cannot be solved by rational categories), inter-culturality describes mutuality in terms of a hermeneutical process of understanding/interpretation, enrichment and critical exchange without the sacrifice of uniqueness."

In order to assist victims and perpetrators in a responsible way on their journey towards healing and wholeness, pastoral care needs to assist the church in creating a space for the victim as well as the perpetrator to face their trauma and to take responsibility for what was done. This space needs to be a dignified one for victims, as well as perpetrators. With an intercultural hermeneutical paradigm as basis, the church has an obligation to listen to the narratives of both the victims and the perpetrators, in this space, to understand and to interpret them in order to assist them in finding meaning on their journey towards healing and wholeness. Victims, as well as perpetrators, need to actively remember their personal hurts, tell their stories and experience that they are accepted/respected/listened to, i.e. loved.

Every South African has a story to tell about the apartheid years. It is the story of what we did, what was done to us and what we failed to do. "I know I should have stood for the truth but I was too scared... What would have happened to me if I had spoken out?"

To put more emphasis on the importance of storytelling, the African American, James Cone (1975:102), states: "Every people have a story to tell, something to say to themselves, their children, and to the world about how they think and live, as they determine their reason for being... When people can no longer listen to other people's stories, they become enclosed within their own social context and then they feel they must destroy other people's stories". Therefore it is clear that human beings cannot survive without a narrative of identity (Ackermann 2001:18).

Story-telling has the ability to help a person to understand the past. This is what (Ackermann 2001:18) calls the 'sense-making function' of a narrative. It also helps a person to remember and not to forget, and it empowers a person to own the story of another person as his/her own. It may be the only basis for recognizing and yet transcending our differences. It may also be the only basis for gaining an understanding of both ourselves and the hopes and fears of others. Victim and perpetrator become part of one another's stories. According to Villa-Vicencio (1995) story-telling is “... the only basis on which different stories, different memories and different histories can emerge as the basis for an inclusive nation-building exercise". 5 To tell your story means that you are able to find and shape yourself through the stories of others. The power of story-telling is not just an individual process, but also a collective one.

Story-telling has the ability to give us insight in our own situation, to change our behaviour and to create new paradigms for a new, healthy life. Telling stories is therefore intrinsic to claiming one's identity and in this process finding impulses of hope (Ackermann 2001:18). This is done by including rituals, symbols and metaphors within the journey to emphasize the fact that we are humans and that we need to deal with the past before we could move on.

Charles Villa-Vicencio, Telling one another stories: towards a theology of reconciliation, in many cultures, one nation, ed. by Charles Villa-Vicencio and Carl Niehaus, 1995. 
For this reason, the church has to create opportunities for people to formulate and tell their stories. It is essentially the responsibility of the faith communities to motivate and facilitate people in this regard.

\section{Understanding the Context of the Victim and Perpetrator}

Let us assume that the legacy of apartheid is the primary cause of much of the violence we experience today. Because of this, people in South Africa still find it difficult to cope with what happened in the past and how to deal with it today. Chubb and Van Dijk (2001:231) describe the effects apartheid had on people as follows: "The South African social fabric was shaped by apartheid laws and structures that exposed the majority of South Africans to oppression, exploitation, depriviation and humiliation."

Black people were excluded from the political system. They were denied proper education. Marks (2001:26) emphasizes this when he remarks that the youth of the early nineties grew up with the legacy of Bantu education. Black schools were understaffed, had little resources and were run according to the apartheid policy of the time. The conditions in the schools were appalling, to say the least. Black pupils left school in the early ' 80 s for a number of reasons. Most common of these were that they were failing repeatedly and had become disillusioned. Students became less and less satisfied with the gutter education they were receiving (Marks 2001:30). Sadly, the education system continues to face enormous challenges today, particular within the rural settings of our country. With the frustration in the schools near boiling point the outbreak of violence was and still is inevitable. Another contributing factor in the increasing frustration of people was and is the stark reality of massive unemployment among black adults.

The final report of the TRC indicated the importance of reparation to the victims: "Victims of human rights abuses have suffered a multiplicity of losses and therefore have the right to reparation. Without adequate reparation and rehabilitation measures, there can be no healing and reconciliation" (TRC of SA Report, Vol. 5, 170). ${ }^{6}$ Although the present government did commit itself towards reparation for victims of apartheid, not much has since occurred in this regard. This added anew to people's frustration and anger.

Although we as South Africans have made considerable progress towards instilling a human rights culture amongst ourselves, there still exits a considerable abuse of foreign migrants. Over the last years xenophobia has become problematic. Those in informal settlements commonly blame foreigners for exacerbating social problems. These range from the rising crime and unemployment rate to the spread of diseases such as malaria and Aids. According to Anthony Minnaar (2005:292), xenophobia is often the irrational fear or hatred of foreigners or even strangers, usually based on misconceptions and misunderstanding of their different race, ethnicity, culture, politics or religion, often reaching violent proportions and acts of violence are almost exclusively directed against black foreigners.

There were others among South Africa's people, however, who actually benefited from the system of apartheid, because they were white. They experienced no problems with education, unemployment or unproductive leisure time because they had what they needed. Their parents, for the most part, had good jobs and benefited greatly because they could usually get what they needed. Because of the policy of separate development many children were raised in an environment which condoned racial prejudice and fear of the 'others', while demanding unquestioning submission to the authority of family and state. This

6 The TRC report (p 170-195) defined clear steps on how reparation and rehabilitation should take place. These steps were put forward by the Committee for Reparation and Rehabilitation. 
eventually resulted in white children being isolated from their peers in other racial groups, be it in their homes, schools, communities or whatever aspect of their lives (Chubb \& van Dijk 2001:231).

Chubb and Van Dijk (2001:233) describe the sociopolitical context in which white young people grew up in an excellent way: "Through the government control of the national media and strategies such as the South African Defence Force (SADF) visits to white schools, young white people were subjected to propaganda. Fear of the 'other' was implanted in children under the guise of an imminent 'Communist' plot, articulated through slogans such as 'total onslaught'. All this contributed to a situation in which most white males concluded that it was their obligation to serve in the armed forces." The white youth were also taught the same message in the churches, thus they had no problem whatsoever to view their participation in the violence committed by the state as fully justified.

Today white people feel that they are discriminated against because of the policy of affirmative action and sporting quotas. Many white people lose their jobs and are not able to find new jobs. This leads to a lot of frustration and violent behaviour. In order to address the challenge of violence, we need to understand the complexities surrounding the so-called 'victim and perpetrator' interrelationship, to be able to assist them in this regard.

\section{Victim}

The United Nations define a victim as “... someone who, individually or collectively, has suffered harm, including physical or mental injury, emotional suffering, economic loss or substantial impairment of their fundamental rights, through acts or omissions that are in violation of criminal laws ... including those laws prescribing criminal abuse of power...the term victim also includes, where appropriate, the immediate family or dependents of the direct victim and persons who have suffered harm in intervening to assist victims in distress or to prevent victimization" (Holtmann, 1998:11).

As indicated earlier, the big challenge is to provide a safe space for the victims to face their trauma. The key is to listen to the deep needs of the victims in mourning in order to move to healing and wholeness. Dorothee Sölle (1973) wrote a standard work in the early seventies about suffering, where she describes suffering as a process. In her book she describes three phases in the process of suffering which will help victims to deal with the suffering they are experiencing. This perspective might help the church to understand and guide victims in their healing process. The phases are as follows:

\section{Suffering causes the Victim to be Powerless and Helpless}

Much of the truth of past and present experiences of violence unfolds via the stories of the human rights violations of the victims. The impact of these disclosures bear witness to the fact that the process of healing, forgiveness and reconciliation is not an easy one, nor may it be evaded or ignored. The extent of the pain of the past experiences is so difficult to deal with by victims and perpetrators alike, that it often seems easier to deny it.

In this phase, victims often experience that they are entirely controlled by the nature of the situation, leaving them to feel totally powerless and helpless. Suffering does not provide you with any room to express yourself. You are in a sense forced to be silent and you become more silent the more you tend to be isolated. Referring to Kobia, Nell (2008:5) correctly makes the assumption that indigenous cultural norms and economic activities were damaged to such an extent that it led to the effect which was probably the biggest colonial heritage, i.e. the silent acceptance of South Africa's imported colonial modernity 
as a norm by people who were humiliated by the system. We therefore need to assist victims to break the silence.

As victims struggle in dealing with the trauma they experience intense feelings such as xenophobia, depression, disillusionment and anger. Krog (1998:160) quotes Nomfundo Walazza, a victim within the apartheid context of South Africa, who concedes that "people make a grave mistake if they assume there is not an immense feeling of outrage among blacks. A crying person and an angry person are two sides of the same coin ... I think black people's anger has been self-contained. And I don't say that all black people are criminals, but when people are saying that crime has increased in the townships, I say it could be expected, because I'm sure it is all due to a lot of pent-up anger that has been there for a long time."

This phase helps to understand the context of the victim and the impact of being powerless and helpless.

\section{Expression and Nomination}

In phase two, victims are empowered to put words to their feelings. This helps them to break the silence they were caught in. The intensity of the emotions they are experiencing as well as the difficulty to communicate it should never be underestimated. It is therefore of the utmost importance to understand the language of their pain within an environment where they feel safe and secure. This will help them to structure their suffering and to communicate it.

The moment the victims are able to put words to their suffering, they begin to turn away from themselves and focus on change. According to Sölle (1973:58), change is not possible without conflict. There will be conflict, because the victim is about to take a risk. Still, it is very positive, because it creates new energy that helps the victims on their journey towards healing and wholeness.

\section{Liberation from Suffering}

As soon as victims succeed in communicating something of their suffering and to focus away from themselves on change, they are ready to be liberated from their pain. It must again be emphasized that this process of healing is neither easy nor cheap, and there are no guarantees for healing. Liberation from suffering is only possible when victims begin to look the past in the eye, face the truth, remember it and continue on their journey of hope and meaning. Liberation from suffering is impossible without the ability to remember. If you cannot or intentionally refuse to remember, it is almost impossible to hope.

\section{Perpetrator}

Kayser (1998:92) distinguishes between a perpetrator and a bystander when she defines the term 'offender'. A perpetrator is someone who actively perpetrates the violation of the human rights of others. A bystander is someone who was present where the human rights of others were violated, but said or did nothing about it. Thesnaar (2001:25) adds another category to the abovementioned, namely those who were not actively or passively involved, but who benefited from the system, either economically, politically, physically, socially or in religious respect.

Pollefeyt (1996:156-171) wrote a very important article in which he wrestled with the following question: Is it possible to forgive someone after he or she has violated the rights 
of human beings? He soon realized that perpetrators are reluctant to take responsibility for the things they have done. To try and address this, he formulates four possible ways in which perpetrators are trying to excuse themselves concerning their responsibility for past offences. It is essential that we understand the reluctance of the perpetrators to take responsibility for what they have done if we want to assist them on their journey towards healing and wholeness.

\section{Demonizing the Offender and the Return of Revenge}

With the term 'demonizing the offender', Pollefeyt (1996:156) explains that the perpetrator is seen, by the so-called 'good' people, as a person who is demonized by evil or that the devil manifests himself in such a person. This implies that such persons are rejected by the 'good' people when they are classified as unjust, because they just want to do evil. When people are viewed in this way, reconciliation, forgiveness and healing are not on the table, but revenge and bitterness are.

People who are found guilty by the 'good' people will be ostracized by society and become more and more isolated. These 'good' people will make very sure that they find someone to blame. Regarding the evils of the past, this reaction by some people regarding others will not help the healing process, because it creates the impression that some people are better than others and only some are guilty.

\section{Bureaucratic Depersonalization of the Offender and the Denial of Guilt}

Pollefeyt (1996:160) describes this approach as the manipulation by the bureaucracy to keep the perpetrator obedient to the system. That is why a number of white people were so obedient to the social system that they would do almost anything asked of them. They cannot, e.g., understand why the fact that they supported the Nationalist Party means that they were also involved in unjust practices. They try to do all they can to deny the past and to excuse themselves from any responsibility. Their famous excuse is: "Let's forget the past and move on", or "Everything cannot be blamed on apartheid".

\section{Whitewashing Evil by morally justifying it}

When perpetrators want to whitewash the evil of the past by morally justifying it, they become participators in the evils perpetrated, although they had the best intentions and were obedient to so-called Christian ethics. In this sense they made sure that they justify themselves in terms of what they did, because to them their deeds were always based on Christian ethics. The problem with a self-justification of this kind is that it is conducive to insensitive behaviour towards other people, and is always inclined to relativize evil.

\section{The Role of Self-delusion and the Importance of Forgiveness}

Perpetrators are often anxious to distinguish between particular social roles which necessarily entail specific obligations and the inner private life where only personal convictions rule. This implies that perpetrators are able to say that their roles at their workplace demanded of them to do certain things, even though it went against their own personal convictions. This is mostly just a way to rationalize their participation.

Where self-delusion is present, evil does not merely manifest itself in what perpetrators do but also in what they fail to do. This leaves them with guilt and fear, which they consistently attempt to deny. They know what to do, but they choose not to. According to Pollefeyt (1996:69), the only way perpetrators can escape the choices they make are to 
manipulate reality by way of psychological self-delusion. In this case also, forgiveness and reconciliation are not on the table, because the perpetrators do not consider it necessary.

From the foregoing it is clear that perpetrators cannot just excuse themselves regarding their individual or collective responsibility for the violation of human rights of other people. Peterson (1996:63) emphasizes the importance of accountability: "For it must be understood by all of us who have benefited from apartheid, that what was done in our name requires our accountability and our personal ownership." With these words he puts an end to the excuse that the perpetrators did not know what was going on, or that they did nothing wrong. To excuse ourselves in regard to the responsibility we have about apartheid, would not only be damaging to ourselves, but to the victims of apartheid as well - and insulting to God with whom they have a relationship.

The church has an obligation to create a space for the perpetrators to take responsibility for their contribution to the past. We are morally accountable. Kayser (1998:91) quotes Schwan who emphatically states that "moral guilt is not inheritable, but the psychological and moral consequences of silencing (guilt), damage the following generations and the basic consensus of democracy."

\section{Conclusion}

The reality in South Africa (and I believe in the rest of the world) is that the divisions, conflicting presuppositions and contradictory worldviews that divided us in the past, continue to undermine the present. One of the ways this manifests in our society is in the form of violence. Violence has a devastating effect on victims, as well as on perpetrators within our society. Violence has a way to highlight the differences within our society, between the rich and the poor and between the victim and the perpetrator. In this regard, Charles Villa-Vicencio remarks that "these differences have the capability of destroying the future". There can be no real understanding between victims and perpetrators from different backgrounds as long as neither has a clear picture of the other, what the other person really thinks and believes in, hope for and feels. I have tried to argue that listening to the narratives of the victims and perpetrators is essential to address the issue of violence and the impact thereof within our society.

Pastoral theology and the church can play a crucial role in combating the impact of violence if it addresses it from a theological intercultural hermeneutical paradigm. Within this paradigm, the church and its ministry has the responsibility to facilitate the healing and reconciliation process between the victim and perpetrator in order to constructively deal with the violence within our society. The church and its ministry need to trust in God to give them the courage, strength and wisdom to make them sensitive for the process of healing and restoring relationships. Only with God, through the love of Jesus Christ and the presence of the Holy Spirit, will people be able to take the risk to reconcile with the other. The reason why the church and its ministry need to drive this process is because it is the ministry of the Bible, the ministry of Hope. 


\section{BIBLIOGRAPHY}

Ackermann, D 2001: Tamar's cry: Re-reading an ancient text in the midst of an HIV/Aids pandemic. In Studies and reports by the Institute for theological \& interdisciplinary research (EFSA).

Babin, P 1991: Biblical Basis for Christian Counseling for People Helpers. Colorado: Navpress.

Chubb, K \& van Dijk, L 2001: Between anger and Hope. South African youth and the Truth and Reconciliation Commission. Johannesburg: Witwatersrand Press

Cone, J 1975: God and the oppressed. New York: Seabury.

Everatt, D \& Sisulu, E 1992: Black youth in Crisis. Facing the future. Braamfontein: Ravan Press.

Gerber, J 2009: Xenofobie-sweer bars. In Die Burger, 18 November 2009, bl. 1.

Holtmann, B 1998: Victim Empowerment. Social Work Practice, 1:8-14.

Kayser, U 1998: Creating the past - Improvising the present. Cape Town: Honours thesis, Centre for African Studies, UCT.

Kraybill, R 1992: The cycle of reconciliation. In Track Two, 19-20.

Krog, A 1998: Country of my Skull. Cape Town: Random House.

Louw, DJ 1995: Wisdom as a New Paradigm for Practical Theology in a Post-Apartheid Society. Journal of theology for Southern Africa, 90:41-54.

Louw, DJ 1998: A Pastoral Hermeneutics of Care and Encounter. Cape Town: Lux Verbi.

Louw, DJ 2008: Cura Vitae. Cape Town: Lux Verbi.

Marks, M 2001: Young warriors. Johannesburg: Witwatersrand University Press.

Minnaar, A 2005: Victimization and the rights of foreign migrants in South Africa. In Victimology in South Africa, by Davis, L \& Snyman, Rika 291-306. Pretoria: Van Schaik.

Mize, Leslye K 1995: Ritual experience and its emergence with story: An experience in meaning in Contemporary Family Therapy (ed.) Balch \& Nicols, vol. 17 no. 1, pp. 109-125.

Nell, I 2008: The tears of Xenophobia: Preaching and violence from a South African perspective. Unpublished article.

Niehaus, C 1995: The truth spoken by many voices in Many cultures, one nation (ed.) Charles Villa-Vicencio \& Carl Niehaus. Cape Town: Human \& Rousseau.

Parret, GA 1999: Ministering in the real world: A multicultural perspective on youth ministry. In: CEJ, 31-45.

Peterson, RM 1996. The politics of grace and the Truth and Reconciliation Commission. In Botman, H R \&Petersen, RM To Remember and Heal. Cape Town: Human \& Rousseau, 57-64.

Pollyfeyt, D 1996. Het onvergeeflijke vergeven? Een etische analyse van kwaad en verzoening. In: Burggraeve, R \& De Tavernier, J (red.). Terugkeer van de wraak?, Averbode: Gooi en Sticht: 155-178.

Sin, S 2008. Hermeneutics and ecclesiology. In, The Routledge companion of the Christian church by Mannion, G \& Mudge Lewis S (ed.) 576-593. New York: Routledge Taylor \& Francis Group. 
Smit, DJ 1998: Biblical hermeneutics: the first 19 centuries. In: Maimela, S, König, A (eds.). Initiation into theology. The rich variety of theology and hermeneutics. Pretoria: Van Schaik.

Sölle, D 1973. Leiden. Stuttgart: Kreuz.

Steven, G \& Lockhat Rafiq, 2003: Black adolescent identity during and after apartheid. In, Social psychology, Identities and relationships by Ratele, K \& Duncan, Norman (eds.) 130-147. Cape Town: UCT Press.

Stevens, G, Seedat, Mohamed \& van Niekerk, Ashley 2003: Understanding and preventing violence. In, Social Psychology, Identities and Relationships by Ratele, K \& Duncan, Norman (eds.) 353-371. Cape Town: UCT Press.

South African Police Services 2009. Crime Situation in South Africa. http://www.saps.gov.za/saps_profile/strategic_framework/annual_report/2008_2009 /2_crime_situation_sa.pdf

Swart, I 2008: Meeting the Challenge of Poverty and Exclusion: The Emerging Field of Development Research in South African Practical Theology. In International Journal of Practical Theology vol. 12, No. 1, (104-149.

Thesnaar, CH 1997: Crossing racial barriers: Story-telling as a method for healing in youth ministry. In Youth Ministry: Basics and beyond (ed.) by Kitching, D \& Robbins, D. Wellington: Youth Specialties 118-132.

Thesnaar, CH 2001: Die proses van heling en versoening: ' $n$ Pastoraal-hermeneutiese ondersoek van die dinamika tussen slagoffer en oortreder binne ' $n$ post-WVK periode. DTh tesis. Stellenbosch: US.

Thiselton, AC 2007: The Hermeneutics of Doctrine. Truth and Reconciliation Commission of South Africa Report. 1998. Cape Town: TRC Vol. 5.

Veltkamp, HJ 1988: Pastoraat als gelijkenis. Kampen: Kok.

Villa-Vicencio, C 1995: Telling one another stories: Towards a Theology of Reconciliation. in Many cultures, one nation, Charles Villa-Vicencio \& Carl Niehaus (eds.). Cape Town: Human \& Rousseau. 